\title{
Immune response of sheep naturally infected with Haemonchus spp. on pastures with two different nutritional conditions
}

\author{
Resposta imune de ovinos naturalmente infectados com \\ Haemonchus spp. em pastagens com duas condições nutricionais \\ diferentes
}

\author{
Gustavo Toscan ${ }^{1 *}$; Gustavo Cauduro Cadore ${ }^{1}$; João Francisco Tadinello Limana ${ }^{2}$; \\ Augusto Weber' ${ }^{2}$ Heloisa Heinloft Palma ${ }^{3}$; Marta Medeiros Frescura Duarte ${ }^{4}$; \\ Luis Antônio Sangioni ${ }^{5}$; Fernanda Silveira Flores Vogel ${ }^{5}$
}

\begin{abstract}
Parasitic nematodes in the gastrointestinal tract of small ruminants are considered one of the main causes of economical and productive losses. Haemonchus contortus is characterized as the major parasite affecting sheep worldwide. This study was designed to evaluate immunological responses in sheep naturally infected with Haemonchus spp. in two different feed grounds: native and cultivated pasture. Fecal and blood samples were collected weekly from fifteen Corriedale sheep, ages 8 to 12 months, to determine the counting of eggs per gram of feces (EPG), and the concentration of haematocrit, eosinophils, and cytokines during an 84-day experiment. Bromatological analysis of the two pasture treatments (types) showed levels of crude protein and non-fibrous carbohydrates of $9.7 \%$ and $12.3 \%$ in the native pasture and $14.3 \%$ and $23.7 \%$ for the cultivated pasture, respectively. No significant difference in haematocrit concentration was found during the experiment between different pastures $(p<0.05)$. However, significant differences were found in EPG, eosinophils, interleukins, and immunoglobulins levels after 21 days in the cultivated (nutritionally-enhanced) pasture. These data suggest that immune response was characterized in sheep by significantly higher peripheral eosinophilia and an increase in serum concentrations of IgE, IgA, IgG, TNF- $\beta$, IFN- $\gamma$, and IL-6. Likewise, the improvement in forage condition resulted in a reduction of EPG and an increase of elements that improve a sheep's immune system response against Haemonchus spp. infection.
\end{abstract}

Key words: Cytokines. Gastrointestinal nematode. Immunity. Protein diet.

\section{Resumo}

Parasitas nematódeos do trato gastrointestinal de pequenos ruminantes são considerados uma das principais causas de perdas econômicas e produtivas. Haemonchus contortus é caracterizado como o parasita mais importante afetando ovinos em todo o mundo. Este estudo foi delineado para avaliar a resposta imunológica de ovinos naturalmente infectados com Haemonchus spp. em dois grupos

\footnotetext{
${ }^{1}$ Discentes do Programa de Pós-Graduação em Medicina Veterinária, Laboratório de Doenças Parasitárias, Universidade Federal de Santa Maria, UFSM, Santa Maria, RS, Brasil. E-mail: gugatoscan@hotmail.com; gustavocadore@yahoo.com.br

${ }^{2}$ Discentes do curso de Medicina Veterinária, UFSM, Santa Maria, RS, Brasil. E-mail: joaolimana@hotmail.com; augustoweber_ rs@hotmail.com

${ }^{3}$ Discentes do Programa de Pós-Graduação em Medicina Veterinária, Laboratório Patologia Clínica Veterinária, UFSM, Santa Maria, RS, Brasil. E-mail: heinloft@hotmail.com

${ }^{4}$ Prof. Dr., Laboratório Labimed - Análises clínicas, Santa Maria, RS, Brasil. E-mail: duartmm@hotmail.com

5 Profs. Drs., Dept ${ }^{\circ}$ de Medicina Veterinária Preventiva, DMVP, UFSM, Santa Maria, RS, Brasil. E-mail: lasangioni@gmail.com; fefevogel@gmail.com

* Author for correspondence
} 
alimentares diferentes: pastagem nativa e cultivada. Amostras de fezes e de sangue foram coletadas semanalmente de quinze ovinos Corriedale, com de 8 a 12 meses de idade, para determinar a contagem de ovos por grama de fezes (OPG), e a concentração do hematócrito, eosinófilos e citocinas durante 84 dias de experimento. Análises bromatológicas dos dois tratamentos de pastagens (tipos) demonstraram níveis de proteína bruta e carboidratos não-fibrosos de $9.7 \%$ e $12.3 \%$ na pastagem nativa e $14.3 \%$ e $23.7 \%$ para pastagem cultivada, respectivamente. Não foi encontrada diferença significativa na concentração do hematócrito durante o experimento entre as diferentes pastagens $(\mathrm{p}<0,05)$. Entretanto, foram encontradas diferenças significativas no OPG, eosinófilos, interleucinas e níveis de imunoglobulinas depois de 21 na pastagem cultivada (melhorada nutricionalmente). Estes dados sugerem que a resposta imune em ovinos foi caracterizada por significativa elevação da eosinofilia periférica e aumento das concentrações séricas de IgE, IgA, IgG, TNF- $\beta$, IFN- $\gamma$, e IL-6. Do mesmo modo, a melhoria nas condições de forragem resultou na redução do OPG e aumento dos elementos que melhoram a resposta do sistema imune de ovinos contra infecção pelo Haemonchus spp.

Palavras-chave: Citocinas. Nematódeos gastrointestinais. Imunidade. Dieta proteica.

\section{Introduction}

Infections by gastrointestinal nematodes are deleterious to the health and productivity of animals. These infections are a major cause of economic losses in small ruminants (SUAREZ et al., 2009). Haemonchus contortus is a blood-feeding, abomasal nematode, which causes reduction of productivity, weight loss, and death in small ruminants (IDRIS et al., 2012). Control of gastrointestinal nematodes is based on repeated use of anthelmintic drugs and complementary field-management practices intended to diminish pasture contamination and reinfection rates. However, clean pasture conditions are not commonly available in semi-intensive grazing systems. In addition, there is an increasing occurrence of resistance among many parasites to anthelmintics (CEZAR et al., 2010). The widespread dissemination of multi-drug resistant parasites highlights the importance of learning more about host-parasite relationships so that new control strategies can be developed against sheep nematodes (BRICARELLO et al., 2004).

Nutrition can influence on the consequences of parasitism in three different ways: (1) hosts can develop tolerance or resilience mechanisms, increasing their ability to overcome detrimental effects of parasites; (2) hosts can develop resistance to parasites, improving their ability to contain or overcome infections by limiting the establishment, growth rate, fecundity and/or persistence of a parasite population; (3) susceptible hosts can counterbalance severe parasitic infestation with good nutrition. Thus, improving host nutrition may provide an alternative to administering drugs to improve host response against parasitic infections, while also reducing potential dependence on anthelmintic drugs (COOP; KYRIAZAKIS, 2001).

The general immune response of sheep infected by Haemonchus spp. is characterized by eosinophilia, mastocytosis, and increased IgA and IgE production (MEEUSEN et al., 2005; SCHALLIG, 2000). Resistant hosts appear to have stronger immune response by $\mathrm{T}$ helper type 2 cells (Th2) in comparison to susceptible hosts (PERNTHANER et al., 2005a; SHAKYA et al., 2009). However, regardless of innate host resistance, some nutrients ingested by hosts, such as fats, appear to have immunosuppressive properties favorable to parasite populations (CHANDRA, 1993). In contrast, evidence shows that protein and carbohydrate intake help to control nematodes in ruminants, by increasing levels of circulating eosinophils and intestinal sheep mast cell proteases (BRICARELLO et al., 2005; SCHAFER et al., 2015; STRAIN; STEAR, 2001). In light of these findings, the objective of this study was to provide a report of the dynamic general and interaction of important factors related to immune response in sheep naturally infected with Haemonchus spp., after grazing in two nutritionally-different pasture habitats: native and cultivated pasture. 


\section{Material and Methods}

Fifteen Corriedale sheep of both genders, aging 8 to 12 months and naturally infected with gastrointestinal nematodes, were kept in grazing areas contaminated by several species of nematodes (Haemonchus spp., Trichostongylus spp. and Teladorsagia spp.). However, Haemonchus spp. were the most prevalent genera, as observed on larvae cultures performed throughout the experimental period. In this experiment, all sheep were first grazed in native pasture for 42 days. After day 42, sheep were transferred to a cultivated pasture dominated by oats (Avena sativa) and ryegrass (Lolium multiflorum), where they were kept until day 84 . Both native and cultivated pastures were 3 hectare (ha) in area. Sheep were evaluated weekly for clinical, parasitological, and hematological conditions throughout the experimental period. The experiment was conducted in the subtropical region of southern Brazil (29S 49' 52.63- 530 42’ 49.66), between February and April of 2014. For similar environmental contamination and parasite challenge in both pastures, sheep density (1.25 sheep ha $\left.{ }^{-1}\right)$ was kept the same for both pasture-types throughout the experiment. Prior to each experiment, pastures were contaminated by allowing other infected sheep (not the experimental animals) to use both pastures for 30 days before the beginning of the experimental period.

Fecal samples were collected individually from sheep, at weekly intervals, to count eggs by McMaster technique. A minimum sensitivity of 100 eggs per gram (EPG) of feces was employed, following Whitlock (1948). Larvae cultures were performed using the Roberts and O'Sullivan modified technique (UENO; GONÇALVES, 1998) and the genera of gastrointestinal nematodes were identified following the recommendations of van Wyk et al. (2004), by counting 100 infective larvae from each collection pool of feces. A coproculture procedure was performed at the beginning and end of each phase of the experiment (native and cultivated pasture).
Peripheral blood samples were collected weekly via jugular vein puncture, with the anticoagulant ethylene diamine tetra acetic acid (EDTA), for the evaluation of the haematocrit and eosinophils counts in total blood, using the method of Lassen and Weiser (2007). The eosinophil counts were performed in a Neubauer chamber using panoptic staining (Panótico rápido, Laborclin, PR, Brazil), according to manufacturer instructions.

Blood samples without anticoagulant were collected weekly, centrifuged $(10 \mathrm{~min}$ at 1000 rpm) and preserved at $-20{ }^{\circ} \mathrm{C}$ until analysis. The concentrations of interleukin-6 (IL-6), IL-10, tumor necrosis factor-beta (TNF- $\beta$ ), interferon-gamma (IFN- $\gamma$ ), immunoglobulin G (IgG), IgA, and IgE levels, were assessed using ELISA kits for sheep, in accordance with the manufacturer's instructions (Cusabio Biotech Co., Ltd., China). These cytokines were chosen to determine correlations among IL-6 and IL-10 and hence, resistance against nematodes, and TNF- $\beta$ and IFN- $\gamma$ concentrations, and hence, susceptibility to parasite infection (ABBAS; LICHTMAN, 2012).

All procedures of animal handling and experimentation were performed according to recommendations of the Brazilian Committee for Experimentation (Cobea; law \# 6.638 of May 8, 1979) and were approved by the Animal Use Ethics Committee (CEUA) of this institution, registration number 127/2014.

\section{Bromatological analysis}

Grass samples were harvested from 15 different areas in each pasture habitat-type, native and cultivated pasture, dominated by A. sativa and L. multiflorum, respectively. All grass samples underwent bromatological analysis, wherein the concentration of crude protein was determined based on total nitrogen content analysis using the method of Weende (AFNOR, 1981). Dietary fiber content was determined by the method of van Soest et al. (1991). 


\section{Statistical analysis}

All data were analyzed using SAS software (SAS Institute Inc., Cary, NC). Data were presented as mean \pm standard deviations and compared using analysis of variance (ANOVA) for repeated measures. Tukey's test was used for post hoc analysis, with a 95\% confidence level $(\mathrm{p}<0.05)$. Because the EPG data were not normal (non-normal data), they were transformed using $\log (x+10)$ to stabilize the variance before further analysis.
Results

\section{Parasitological data}

The relocation of sheep from native to cultivated pasture resulted in a significant reduction in EPG (Fig. 1). Mean EPG ranged from 600 (at day 7) up to 1400 (at day 35) in native pasture and was 1200 by the time sheep were transferred to the cultivated pasture (at day 42). After 21 days in cultivated pasture (day 70), mean EPG had been significantly reduced to $<100$ (Figure 1).

Figure 1. Mean eggs per gram (EPG) and standard deviation of the mean in sheep naturally infected with Haemonchus spp. Day 42 corresponds to date at which sheep were transferred to cultivated pasture. Different letters in each region indicate where significant differences occur between means $(\mathrm{p}<0.05)$.

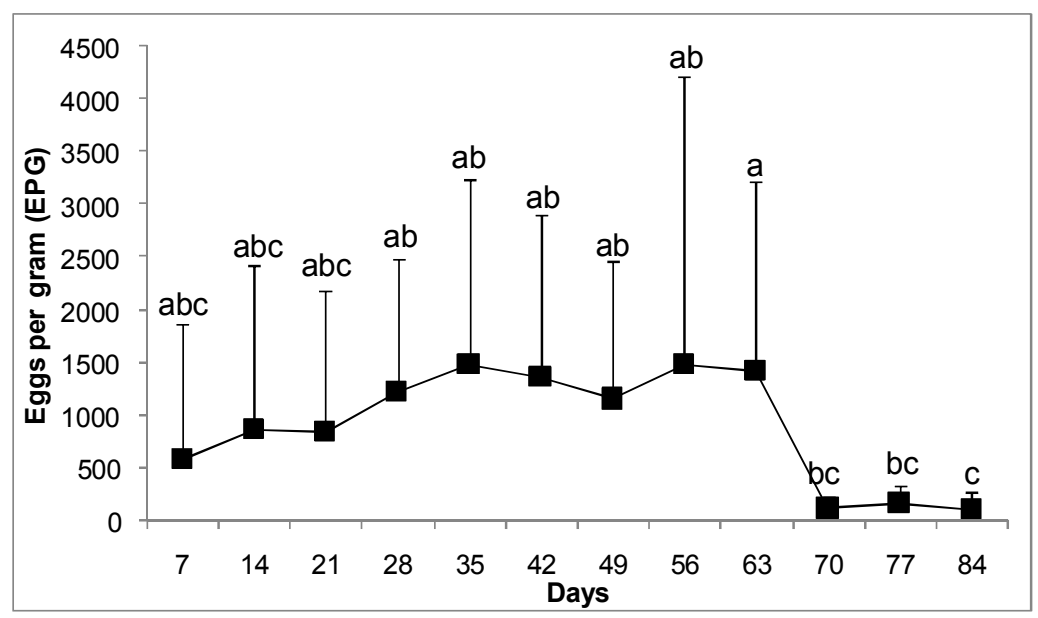

Mean EPG did not differ significantly between the first and last day of analysis (day 7 and day 42, respectively) for sheep grazing in native pasture. Haemonchus spp. dominated in feces in the flock throughout all the experimental period, as shown by the larvae cultures performed in fecal collections (Haemonchus spp. $=90 \%$, Trichostongylus spp. $=$ $7 \%$, and Teladorsagia spp. $=3 \%$ ). In addition, there were no differences between mean EPG on the first (day 7) and last day (day 84) of the experiment, considering the total period of evaluation (Fig. 1). However, mean EPG was higher at the time animals were removed from the native pasture (day 42) than at day 84,42 days after starting to graze in the cultivated pasture $(\mathrm{p}<0.05)$.

\section{Immune response}

Haematocrit and circulating eosinophil concentrations

No significant difference was found in haematocrit levels throughout the entire study ( $p<$ 0.05) (Fig 2). For sheep native pasture, the mean concentration of circulating eosinophils decreased from 562 eosinophil/ $\mu$ l (day 7) to 207 eosinophil/ $\mu 1$ (day 21) during the grazing period, while in cultivated pasture, eosinophils increased from 379 eosinophil/ $\mu$ l (day 42) to a peak of 867 eosinophils/ $\mu 1$ (day 70), after 28 days of grazing. This peak of eosinophil concentration at day 70 was higher ( $p$ $<0.05)$ than any concentration observed in native 
pasture (Figure 3). Increased levels of eosinophil

from day 70 until the end of the experimental period were associated with a reduction in EPG $(p<0.05)$

(day 84) (Figure 1 and Figure 3).

Figure 2. Mean and standard deviation of haematocrit level in sheep naturally infected with Haemonchus spp. Day 42 corresponds to date at which sheep were transferred to cultivated pasture. No significant difference was found in haematocrit levels throughout the entire study $(\mathrm{p}>0.05)$.

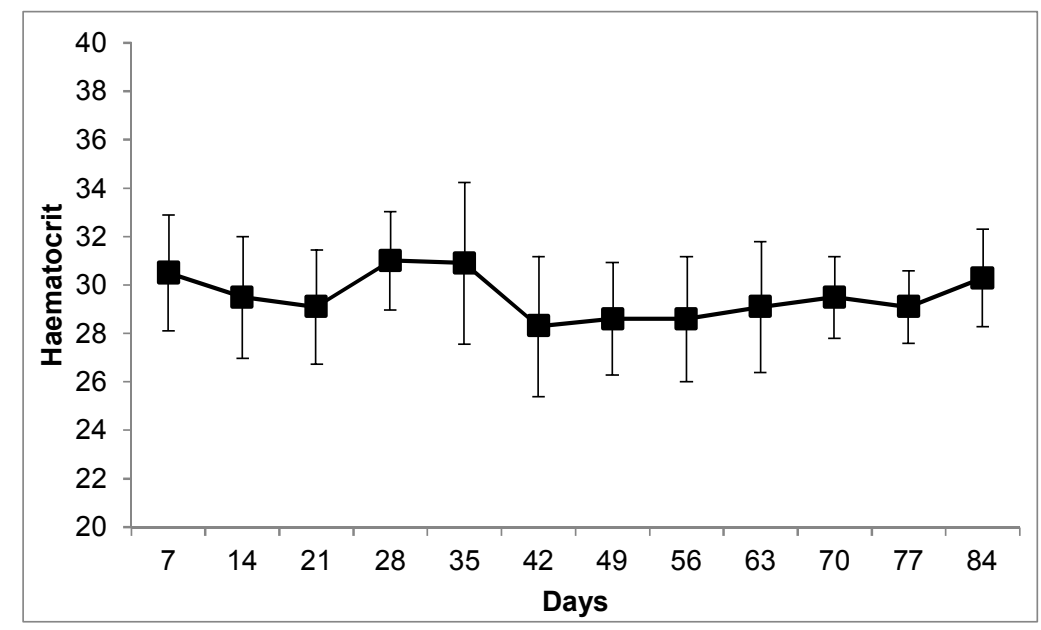

Figure 3. Mean of eosinophil concentration and standard deviation of the mean in sheep naturally infected with Haemonchus spp. Day 42 corresponds to date at which sheep were transferred to cultivated pasture. Different letters in each region indicate where significant differences occur between means $(\mathrm{p}<0.05)$.

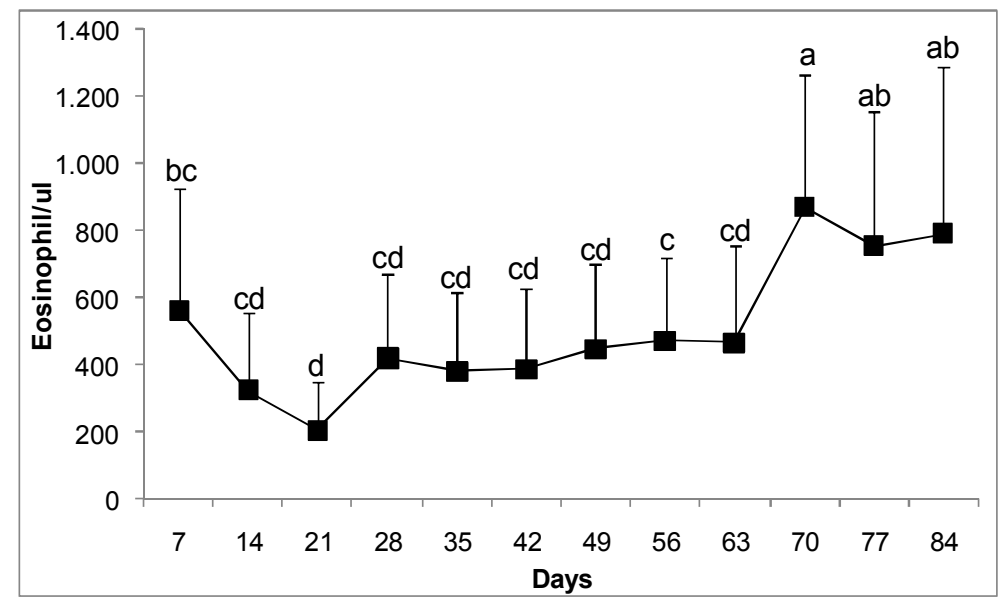

\section{Interleukins level}

TNF- $\beta$, IFN- $\gamma$ and IL-6 levels increased in sheep, while IL-10 levels decreased only during the period of grazing in cultivated pasture (Figure 4). Significant differences in evaluated interleukins were observed between day 7 and day 84 . In comparing the first (day 7) with the last (day 84) day of the experiment, mean values for interleukins increased from 124.3 to $144.3 \mathrm{pg} / \mathrm{mL}$ for IL-6, from 167.3 to $195.9 \mathrm{pg} / \mathrm{mL}$ for IFN- $\gamma$, and from 143.9 to $148.9 \mathrm{pg} /$ $\mathrm{mL}$ for TNF- $\beta$ (Figure 4). In contrast, mean IL-10 concentration decreased from 84.9 (day 7) to 47.9 $\mathrm{pg} / \mathrm{mL}$ (day 84) (Figure 4). In addition, significant 
changes $(\mathrm{p}<0.05)$ in interleukin levels (increase or decrease) were observed from 21 days (day 63) after sheep were transferred to cultivated pasture until the end of the study (day 84).

Figure 4. Means and standard deviations of interleukin-6 - IL-6 (a) IL-10, (b) tumor necrosis factor-beta - TNF- $\beta$ (c) and interferon-gamma - IFN- $\gamma$, (d) in serum of sheep naturally infected with Haemonchus spp. Day 42 corresponds to date at which sheep were transferred to cultivated pasture. Different letters in each region indicate where significant differences occur between means $(\mathrm{p}<0.05)$.
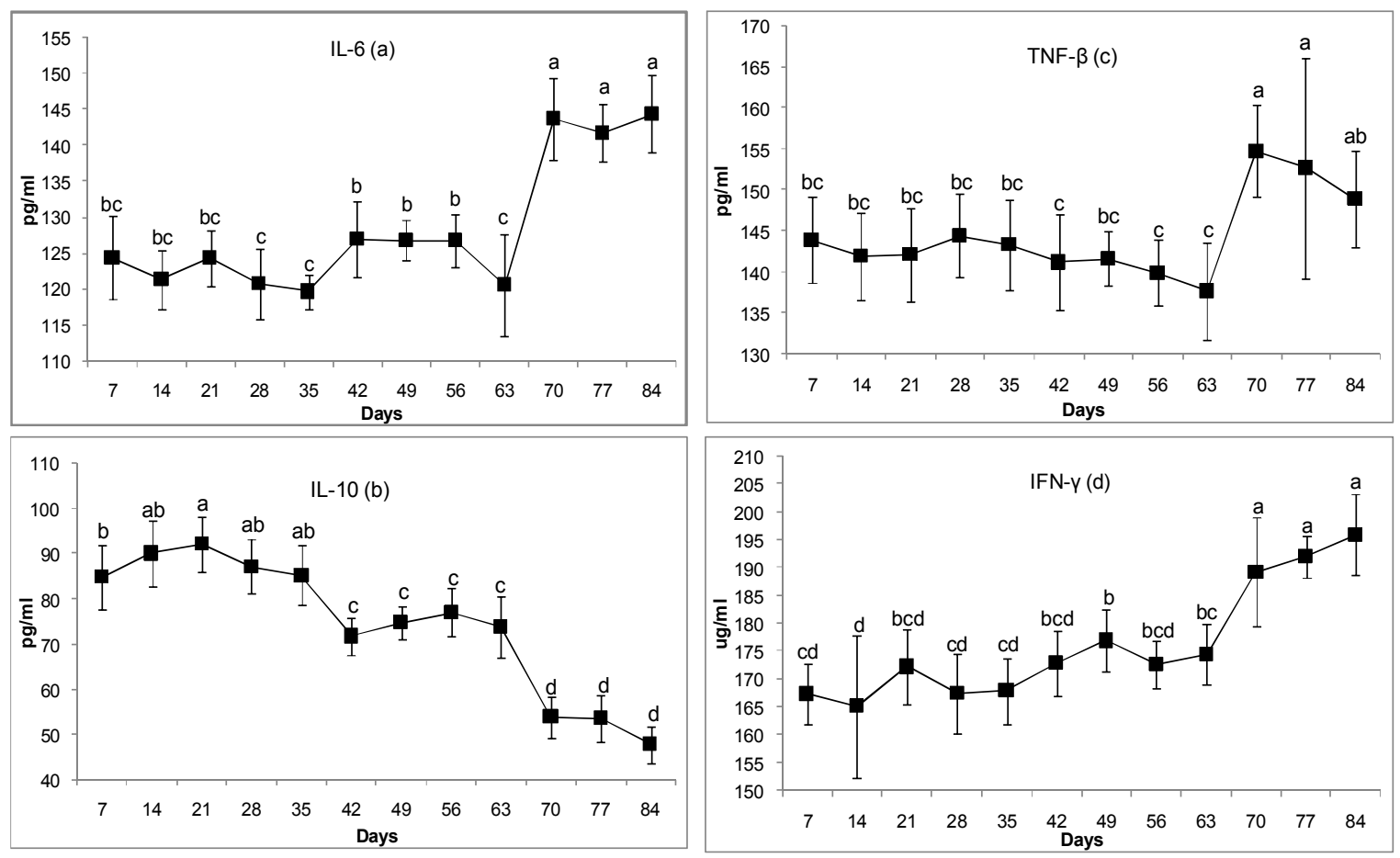

\section{Serum immunoglobulins}

Significant differences in serum concentrations of immunoglobulin isotypes $\operatorname{IgA}, \operatorname{IgG}$, and $\mathrm{IgE}$ were detected in sheep grazing in native and cultivated pasture treatments $(\mathrm{p}<0.05)$. Immunoglobulin levels remained similar for 21 days after sheep were transferred to cultivated pasture (day 63). However, serum levels of immunoglobulins $\operatorname{IgA}$, IgG, and IgE were found to increase $(p<0.05)$ from day 63 until the end of the experimental period (day 84).

\section{Pasture analysis}

Native pasture was composed of $42.5 \%$ dry matter (DM), 84.2\% organic matter (OM), 9.7\% crude protein (CP), $1.5 \%$ ether extract (EE), $12.3 \%$

non-fibrous carbohydrates (NFC), and 60.7\% neutral detergent fiber (NDF). In contrast, the more nutritious, cultivated pasture consisted of $22.4 \%$ DM, 88.7\% OM, 14.3\% CP, 2.4\% EE, $23.7 \%$ NFC, and $48.3 \% \mathrm{NDF}$.

\section{Discussion}

Resistance to nematodes is defined as the ability of an animal to prevent the establishment of larvae in its gastrointestinal tract and eliminate parasites already established there (MAIZELS et al., 2012; TIZARD, 2008). Parasitological and immunological parameters (such as immunoglobulins, defense cells, and cytokines) are frequently used as markers for resistance. In our study, the evaluation of these 
parameters revealed significant differences in factors related to the immune response of sheep grazed in two nutritionally-different pastures. Most of the variables considered indicators of higher resistance to parasitism by gastrointestinal nematodes were found to increase under the better forage condition (cultivated pasture), indicating that greater energy intake and higher levels of protein ingestion were directly linked to an enhanced ability of the immune system to fight parasites.

The effects of nematode infection have been shown to be influenced by the nutritional status of the host organism (KNOX et al., 2003). That is, well-fed animals can better withstand infection than animals kept under conditions where diet is inadequate. It is also been shown that nematodes interfere with the ability of a host to efficiently utilize nutrients (MILLER; HOROHOV, 2006). In general, gastrointestinal nematodes reduce nutrient availability to the host, depress appetite and foraging behavior, and/or reduce nutrient absorption efficiency (COOP; KYRIAZAKIS, 2001). In the present study, we observed that an adaptive period of approximately 21 days was required following an improvement in diet (from native to cultivated pasture) to promote an increase in blond serum factors. Thus, this reflex in the components of immunological response is not instantaneous, but takes place gradually as sheep incorporate higher quality nutrients from their diet over time, as demonstrated by changes in EPG, eosinophils, and cytokines (Figures 1, 3 and 4).

EPG is the parameter that best correlates with parasite burden in sheep (MOLENTO et al., 2011). An improvement in the nutritional quality of pasturage led to a reduction in EPG, indicating a reduction in spoliation caused by haemonchosis. The lower EPG counts, obtained 28 days after pasture change could be due to several factors such as: inhibition in the establishment of infective larvae; suppression of parasitic egg production caused by diminished pasture contamination and re-infection rate; and, a significant improvement in immunological factors important to infected sheep as a result of better nutrition.

A decrease in EPG coincided with decreasing IL-10 concentration and increasing IL- 6 , TNF- $\beta$, IFN- $\gamma$, IgA, IgE and IgG levels. The reduction in EPG that occurred 28 days after sheep were moved to higher-nutrition (cultivated) pasture may indicate of self-cure with elimination of adult parasites and/ or reduce their fecundity.

Eosinophils are important factors controlling immune response against helminths. Eosinophilia, both in blood and in tissues, is frequently associated with higher protection and resistance against nematodes (BALIC et al., 2006). The noticeable eosinophilia observed after sheep were moved to nutritionally-superior pasture, suggests the involvement of these cells in the prevention of, or protection from, larval stages of helminth in sheep.

Immunity against gastrointestinal nematodes also involves production of $\operatorname{IgA}, \operatorname{IgG}$, and $\mathrm{IgE}$. IgA production may be a major mechanism in controlling fecundity of Haemonchus spp. and the magnitude of response is influenced by diet quality (STRAIN; STEAR, 2001). An increase in total and parasitespecific $\operatorname{IgE}$ is an important indicator of in the host response to helminth infection (HAGAN, 1993). $H$. contortus infection induces an increase in serum IgE levels in sheep at 2-4 weeks after infection and there is negative correlation between total IgE serum levels and parasite counts at necropsy (KOOYMAN et al., 1997). Further, eosinophils and IgE are involved in antibody-dependent, cellmediated cytotoxicity. Therefore, eosinophilia and increased IgE levels may indicate anti-Haemonchus resistance in sheep (SHAKYA et al., 2009).

Indoor-raised sheep experimentally infected with nematodes showed less-severe pathophysiological consequences of infection when their diet of metabolizable protein was increased (SAYERS; SWEENEY, 2005). Protein supplementation was associated with better capacity to fight infection, indicated by lower levels of parasite eggs excretion 
in feces (ETTER et al., 2000). Reductions in other blood parameters, such as hematocrit, total serum protein, and albumin concentrations, were lower in animals fed a high level of metabolizable protein than in animals that only had access to low to moderate protein supplements (COOP; KYRIAZAKIS, 2001). In contrast, in our study, although the sheep received a higher-quality diet by changing grazing habitat, hematocrit parameters did not changed significantly.

When innate mechanisms fail to prevent larval establishment in the gastrointestinal mucosa, the immune system reacts with a specific response to the invading agent. Delayed expulsion of Haemonchus spp. larvae occurs by specific immune response mounted against the larvae in the abomasum glands. This action is regulated by lymphocytes, IgA and IgE antibodies, eosinophils, and the classical complement pathway (BALIC et al., 2002).

Mucosal mast cells, eosinophils, and immunoglobulins are components commonly evaluating anti-parasite immunity, since they play a major role in effective protection against helminthes (LACROUX et al., 2006). However, the immune response against gastrointestinal parasites is complex, and the contribution of each of the listed components can vary without necessarily interfering with the general effectiveness of the immunological response (MEEUSEN et al., 2005). This study showed that an improvement in the nutritional value of a grassland favorably influences immunological parameters studied in sheep, revealing a potential increase in the immunological response of sheep to meet the challenges of gastrointestinal parasites.

Sheep response to gastrointestinal nematode infection can also be mediated by Th1 or Th2 lymphocytes. Th1 lymphocytes produce several cytokines, notably IL- 2 , IFN- $\gamma$, and TNF- $\beta$, resulting in a cell mediated-immune response. The Th2 lymphocytes response is characterized by increased immunoglobulin secretion by B cells, mainly IgG and IgE, and proliferation of eosinophils (SCHALLIG,
2000). A typical characteristic of helminthic infections is the induction of a specific IgE response, which results from a Th2 stimulation. However, individual, nutritional or parasitic factors can also influence this condition. IgE induces antibodydependent cytotoxicity in eosinophils, mast cells, and macrophages. Thus, increased IgE levels have been shown to effectively combat gastrointestinal nematodes in sheep (PERNTHANER et al., 2005b; 2006). In in vitro assays, IgE recognizes nematode surface allergens and guides eosinophils and mast cells to attack the parasite cuticle (TEREFE et al., 2009).

The decrease in the concentration of IFN- $\gamma$ from day 63 onward, may indicate an exchange to in the Th2 type pattern of immune response of the sheep. This is because IFN- $\gamma$ is the main macrophageactivating cytokine and is very important in the response against intracellular agents (TIZARD, 2008). However, in the latter period of foraging (day 63 onward) in the nutritionally-enhanced pasture, some components of cellular immune response have increased, such as, eosinophils and IgE concentrations. In addition, since IFN- $\gamma$ and IL-10 are antagonists, in that IL-10 seems to inhibit IFN- $\gamma$ production (ENDHARTI et al., 2005), presenting different serological behavior from pasture exchange onward.

Th1 and Th2 responses are also antagonistic to each other and interleukins control this activity. Th2 response inhibits Th1 response through IL-10 signaling (GILL et al., 2000). Blood lymphocytes from lambs produce less IFN- $\gamma$, and so in general, young sheep mount a weaker antibody response than do mature animals (WALLER; THAMSBORG, 2004). These findings may explain why EPG showed a significant reduction in concentration, while IFN- $\gamma$ levels increased.

The constant increase through time in IL-6 concentration may be associated with an increased IgG level and amplified number of circulating eosinophils (Figure4 and 5). Even though IL-10 is 
known to involve the ability to inhibit activation of macrophage activity (ABBAS; LICHTMAN, 2012), a decreased expression of IL-10, clearly observed at day 70 , can be interpreted as being caused by a synergistic effect between IL-6 and IL-10, in turn activated by stimulation of the Th2 response pathway.

Figure 5. Means and standard deviations of immunoglobulins in serum of sheep naturally infected with Haemonchus spp.. Day 42 corresponds to date at which sheep were transferred to cultivated pasture. Different letters in each region indicate where significant differences occur between means $(\mathrm{p}<0.05)$.

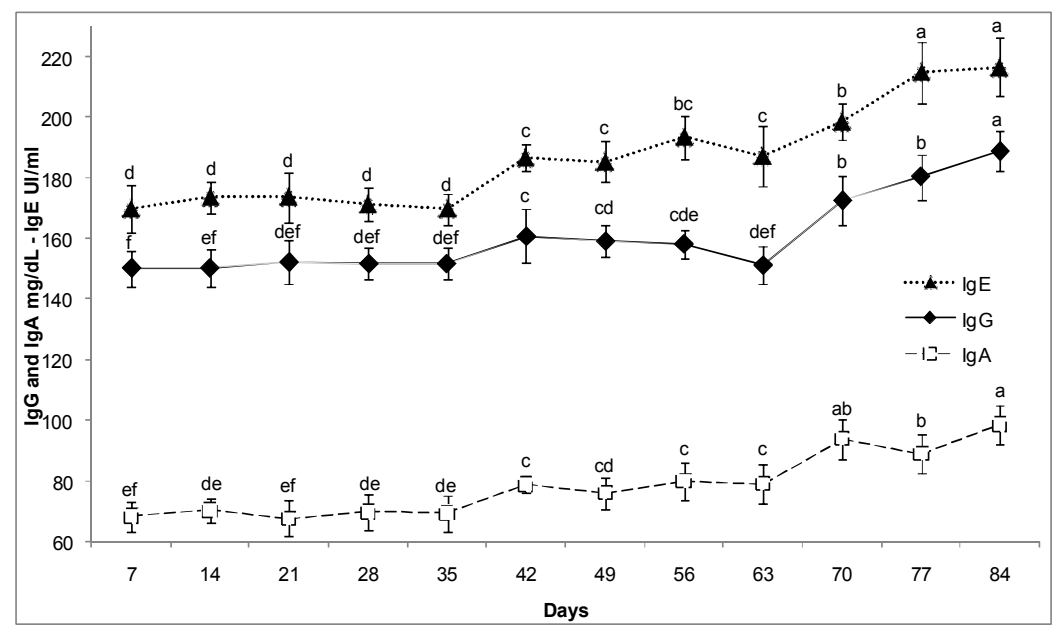

Increased dietary protein appears to be an attractive strategy for improving the reaction against gastrointestinal nematodes in sheep, and thus potentially reducing the reliance on anthelmintic drugs. Our results reinforce the premise that parasite-infected animals eating a higher protein and carbohydrate diet can show a significant improvement in their clinical condition, as indicated by a reduction in EPG and an increase in factors that support the ability to combat gastrointestinal parasites (KNOX et al., 2006; NNADI et al., 2007). Further, as shown by Bricarello et al. (2005) and Louvandini et al. (2006), protein intake overcomes the debilitating effects and clinical symptoms caused by haemoncose in sheep. Therefore, nutritional status of the host can influence the rate and rapidity of immune response against gastrointestinal parasites (BRICARELLO et al., 2005; LOUVANDINI et al., 2002).

\section{Conclusion}

Improved forage conditions for sheep promoted a reduction in EPG and improved conditions that favor the ability of sheep to strengthen their immune systems. Specifically, improved nutritional support significantly increased peripheral eosinophilia and serum concentrations of $\operatorname{IgE}, \operatorname{IgA}, \operatorname{IgG}, \mathrm{TNF}-\beta$, IFN- $\gamma$, and IL- 6 . The relocation of sheep to nutritionally-superior pasturage promoted a gradual increase in their blood serum immunological factors after an adaptive period of 21 days.

\section{References}

ABBAS, A. K.; LICHTMAN, A. H. Cellular and molecular immunology. $7^{\text {th }}$ ed. Philadelphia: Saunders, 2012. $560 \mathrm{p}$.

ASSOCIATION FRANÇAISE DE NORMALISATION - AFNOR. Cellulose brute, méthode CCE 4ème directive norme NF V 03040 in aliments des animaux in: méthodes d'analyse. Paris: Ed. Afnor, 1981. 
BALIC, A.; BOWLES, V. M.; MEEUSEN, E. N. T. Mechanisms of immunity to Haemonchus contortus infection in sheep. Parasite Immunology, Oxford, v. 24, n. 1, p. 39-46, 2002.

BALIC, A.; CUNNINGHAM, C. P.; MEEUSEN, E. N. T. Eosinophil interactions with Haemonchus contortus larvae in the ovine gastrointestinal tract. Parasite Immunology, Oxford, v. 28, n. 3, p. 107-115, 2006.

BRICARELLO, P. A.; AMARANTE, A. F. T.; ROCHA, R. A.; CABRAL FILHO, S. L.; HUNTLEY, J. F.; HOUDIJK, J. G. M.; ABDALLA, A. L.; GENNARI, $\mathrm{S}$. M. Influence of dietary protein supply on resistance to experimental infections with Haemonchus contortus in Ile de France and Santa Ines lambs. Veterinary Parasitology, Amsterdam, v. 134, n. 1, p. 99-109, 2005.

BRICARELLO, P. A.; GENNARI, S. M.; OLIVEIRASIQUEIRA, T. C. G.; VAZ, C. M. S. L.; GONÇALVES, I. de; ECHEVARRIA, F. A. M. Worm burden and immunological responses in Corriedale and Crioula Lanada sheep following natural infection with Haemonchus contortus. Small Ruminant Research, Dinamarca, v. 51, n. 1, p. 75-83, 2004.

CEZAR, A. S.; TOSCAN, G.; CAMILlO, G.; SANGIONI, L. A.; RIBAS, H. O.; VOGEL, F. S. Multiple resistance of gastrointestinal nematodes to nine different drugs in a sheep flock in southern Brazil. Veterinary Parasitology, Amsterdam, v. 173, n. 1, p. 157-160, 2010.

CHANDRA, R. K. Nutrition and the immune system. Proceedings of the Nutrition Society, Cambridge, v. 52, n. 1, p. 77-84, 1993.

COOP, R. L.; KYRIAZAKIS, I. Influence of host nutrition on the development and consequences of nematode parasitism in ruminants. Trends in Parasitology, Oxford, v. 17, n. 7, p. 325-330, 2001.

ENDHARTI, A.T.; RIFA'I, M.; SHI, Z.; FUKUOKA, Y.; NAKAHARA, Y.; KAWAMOTO, Y.; TAKEDA, K.; ISOBE, K.; SUZUKI, H. Cutting Edge: $\mathrm{CD}^{+} \mathrm{CD} 122^{+}$ regulatory $\mathrm{T}$ cells produce IL-10 to suppress IFN- $\gamma$ production and proliferation of $\mathrm{CD}^{+} \mathrm{T}$ cells. Journal of Immunology, Baltimore, v. 175, n. 11, p. 7093-7097, 2005.

ETTER, E. The effect of two levels of dietary protein on resistance and resilience of dairy goats experimentally infected with Trichostrongylus colubriformis: comparison between high and low producers. Veterinary Research, Paris, v. 31, n. 2, p. 247-258, 2000.

GILL, H. S.; ALTMANN, K.; CROSS, M. L.; HUSB, A. $\mathrm{J}$. Induction of $\mathrm{T}$ helper 1- and $\mathrm{T}$ helper 2-type immune responses during Haemonchus contortus infection in sheep. Immunology, Oxford, v. 99, n. 3, p. 458-463, 2000.
HAGAN, P. IgE and protective immunity to helminth infections. Parasite Immunology, Oxford, v. 15, n. 1, p. 1-4, 1993.

IDRIS, A.; MOORS, E.; SOHNREY, B.; GAULY, M. Gastrointestinal nematode infections in German sheep. Parasitology Research, Berlin, v. 110, n. 4, p. 14531459, 2012.

KNOX, M. R.; STEEL, J. W.; ANDERSON, C. A.; MUIR, L. L. Nutrition-parasite interactions in sheep. Australian Journal of Experimental Agriculture, v. 43, p. 1383-1488, 2003. Special Issue.

KNOX, M. R.; TORRES-ACOSTA, J. F. J.; AGUILARCABALLERO, A. J. Exploiting the effect of dietary supplementation of small ruminants on resilience and resistance against gastrointestinal nematodes. Veterinary Parasitology, Amsterdam, v. 139, n. 4, p. 385-393, 2006.

KOOYMAN, F. N.; VAN KOOTEN, P. J.; HUNTLEY, J. F.; MACKELLAR, A.; CORNELISSEN, A. W.; SCHALLIG, H. D. Production of a monoclonal antibody specific for ovine immunoglobulin $\mathrm{E}$ and its application to monitor serum IgE responses to Haemonchus contortus infection. Parasitology, London, v. 114, n. 04, p. $395-$ 406, 1997.

LACROUX, C.; NGUYEN, T. H.; ANDREOLETTI, O.; PREVOT, F.; GRISEZ, C.; BERGEAUD, J. P.; GRUNER, L.; BRUNEL, J. C.; FRANCOIS, D.; DORCHIES, P.; JACQUIET, P. Haemonchus contortus (Nematoda: Trichostrongylidae) infection in lambs elicits an unequivocal Th2 immune response. Veterinary Research, Paris, v. 37, n. 4, p. 607-622, 2006.

LASSEN, E. D.; WEISER, G. Tecnologia laboratorial em medicina veterinária. Hematologia e bioquimica clínica veterinária. 8. ed. São Paulo: Roca, 2007. 36 p.

LOUVANDINI, A. L.; ABDALLA, A. L.; COOP, R. L.; MCMANUS, C. M.; GENNARI, S. M. Effect of dietary protein intake on the resilience of calves to Haemonchus placei infection. Brazilian Journal of Veterinary Research and Animal Science, São Paulo, v. 39, n. 5, p. 227-23, 2002.

LOUVANDINI, H.; VELOSO, C. F. M.; PALUDO, G. R.; DELL'PORTO, A.; GENNARI, S. M.; MCMANUS, C. M. Influence of protein supplementation on the resistance and resilience on young hair sheep naturally infected with gastrointestinal nematodes during rainy and dry seasons. Veterinary Parasitology, Amsterdam, v. 137, n. 1, p. 103-111, 2006.

MAIZELS, R. M.; HEWITSON, J. P.; SMITH, K. A. Susceptibility and immunity to helminth parasites. Current Opinion in Immunology, Philadelphia, v. 24, n. 4, p. 459-466, 2012. 
MEEUSEN, E. N.; BALIC, A.; BOWLES, V. Cells, cytokines and other molecules associated with rejection of gastrointestinal nematode parasites. Veterinary Immunology and Immunopathology, Amsterdam, v. 108, n. 1, p. 121-125, 2005.

MILLER, J. E.; HOROHOV, D. W. Immunological aspects of nematode parasite control in sheep. Animal Science, Liverpool, v. 84, n. 13, p. 124-132, 2006.

MOLENTO, M. B.; FORTES, F. S.; PONDELEK, D. A. S.; ALMEIDA BORGES, F. de; SOUZA CHAGAS, A. C. de; TORRES-ACOSTA, J. F. D. J.; GELDHOF, P. Challenges of nematode control in ruminants: focus on Latin America. Veterinary Parasitology, Amsterdam, v. 180, n. 1, p. 126-132, 2011.

NNADI, P. A.; KAMALU, T. N.; ONAH, D. N. The effect of dietary protein supplementation on the pathophysiology of Haemonchus contortus infection in West African Dwarf goats. Veterinary Parasitology, Amsterdam, v. 148, n. 3-4, p. 256-261, 2007.

PERNTHANER, A.; COLE, S. A.; MORRISON, L.; GREEN, R.; SHAW, R. J.; HEIN, W. R. Cytokine and antibody subclass responses in the intestinal lymph of sheep during repeated experimental infections with the nematode parasite Trichostrongylus colubriformis. Veterinary Immunology and Immunopathology, Amsterdam, v. 114, n. 1, p. 135-148, 2006.

PERNTHANER, A.; COLE, S. A.; MORRISON, L.; HEIN, W. R. Increased expression of interleukin-5 (IL-5), IL-13, and tumor necrosis factor alpha genes in intestinal lymph cells of sheep selected for enhanced resistance to nematodes during infection with Trichostrongylus colubriformis. Infection and Immunity, Washington, v. 73, n. 4, p. 2175-2183, 2005a.

PERNTHANER, A.; SHAW, R. J.; MCNEILL, M. M.; MORRISON, L.; HEIN, W. R. Total and nematodespecific IgE responses in intestinal lymph of genetically resistant and susceptible sheep during infection with Trichostrongylus colubriformis. Veterinary Immunology and Immunopathology, Amsterdam, v. 104, n. 1, p. 6980, 2005b.

SAYERS, G.; SWEENEY, T. Gastrointestinal nematode infection in sheep-a review of the alternatives to anthelmintics in parasite control. Animal Health Research Reviews, Cambridge, v. 6, n. 2, p. 159-171, 2005.

SCHAFER, A. S.; LEAL, M. L. R.; MOLENTO, M. B.; AIRES, A. R.; DUARTE, M. M. F.; CARVALHO, F. B.; TONIN, A. A.; SCHMIDT, L.; FLORES, E. M. M.; FRANÇA, R. T.; GRANDO, T. H.; MINHO, A. P.; KRAUSE, A.; ANTONIAZZI, A. Q.; LOPES. S. T. A. Immune response of lambs experimentally infected with Haemonchus contortus and parenterally treated with a combination of zinc and copper. Small Ruminant Research, Arkansas, v. 123, n. 1, p. 183-188, 2015.

SCHALLIG, H. D. F. H. Immunological responses of sheep to Haemonchus contortus. Parasitology, London, v. 120 , n. 07 , p. $63-72,2000$.

SHAKYA, K. P.; MILLER, J. E.; HOROHOV, D. W. A Th2 type of immune response is associated with increased resistance to Haemonchus contortus in naturally infected Gulf Coast Native lambs. Veterinary Parasitology, Amsterdam, v. 163, n. 1, p. 57-66, 2009.

STRAIN, S. A. J.; STEAR, M. J. The influence of protein supplementation on the immune response to Haemonchus contortus. Parasite Immunology, Oxford, v. 23, n. 10, p. 527-531, 2001.

SUAREZ, V. H.; CRISTEL, S. L.; BUSETTI, M. R. Epidemiology and effects of gastrointestinal nematode infection on milk productions of dairy ewes. Parasite, Paris, v. 16, n. 2, p. 141-147, 2009.

TEREFE, G.; LACROUX, C.; PRÉVOT, F.; GRISEZ, C.; BERGEAUD, J. P.; BLEUART, C.; DORCHIES, P.; FOUCRAS, G.; JACQUIET, P. Eosinophils in Haemonchus contortus-infected resistant and susceptible breeds of sheep: abomasal tissue recruitment and in vitro functional state. Veterinary Parasitology, Amsterdam, v. 165, n. 1, p. 161-164, 2009.

TIZARD, I. Imunologia veterinária: uma introdução. 8. ed. Rio de Janeiro: Elsevier Saunders, 2008. 587 p.

UENO, H.; GONÇALVES, V. C. Manual para diagnóstico das helmintoses de ruminantes. Tóquio: Japan International Cooperation Agency, 1998. 143 p.

VAN SOEST, P. J.; ROBERTSON, J. B.; LEWIS, B. A. Methods for dietary fiber, neutral detergent fiber, and non-starch polysaccharides in relation to animal nutrition. Journal of Dairy Science, Champaign, v. 74, n. 10, p. 3583-3597, 1991.

VAN WYK, J. A.; CABARET, J.; MICHAEL, L. M. Morphological identification of nematode larvae of small ruminants and cattle simplified. Veterinary Parasitology, Amsterdam, v. 119, n. 4, p. 277-306, 2004.

WALLER, P. J.; THAMSBORG, S. M. Nematode control in 'green' ruminant production systems. Trends in parasitology, Oxford, v. 20, n. 10, p. 493-497, 2004.

WHITLOCK, H. R. Some modifications of the McMaster helminth egg-counting technique apparatus. Journal Council for Scientific and Industrial Research, Nova Delhi, v. 21, n.3, p. 177-180, 1948. 
